\title{
Pterocarpans and a Novel Flavanone from Harpalyce brasiliana Roots
}

\author{
Renata M. de Araújo, Mary Anne S. Lima and Edilberto R. Silveira* \\ Departamento de Química Orgânica e Inorgânica, Centro de Ciências, Universidade Federal do Ceará, \\ CP 12200, 60451-970 Fortaleza-CE, Brazil
}

\begin{abstract}
A nova “(-)-7,8,3',4'-tri-hidróxi-8-(3",7"-dimetil-octa-2",6"-dienoil)-flavanona foi isolada a partir do extrato etanólico das raízes de Harpalyce brasiliana, juntamente com os pterocarpanos conhecidos (-)-2-geranil-3-hidróxi-8,9-metilenodioxipterocarpano, harpalicina, medicarpina, maackiaina e as cabenegrinas A-I e A-II. Os metabólitos isolados foram caracterizados com base nos seus dados espectroscópicos, principalmente RMN uni e bidimensional.
\end{abstract}

The novel (-)-7,8,3',4'-trihydroxy-8-(3",7'-dimethyl-octa-2",6"-dienoyl)-flavanone was isolated from the EtOH extract from the roots of Harpalyce brasiliana (Leguminosae) together with the known pterocarpans (-)-2-geranyl-3-hydroxy-8,9-methylenedioxypterocarpan, harpalicin, medicarpin, maackiain and cabenegrins A-I and A-II. The isolated metabolites were characterized on the basis of spectroscopic data, mainly 1D and 2D NMR.

Keywords: Harpalyce brasiliana, flavanone, pterocarpans, NMR assignments

\section{Introduction}

Medicinal plants have often been used by humans in folk medicine to treat snakebites envenomation as an alternative and supplementary therapy. Previous studies on the anti-ophidian activity of extracts and fractions of several Brazilian plant species used popularly in some communities have been investigated scientifically. ${ }^{1-7}$ Among the class of the pharmacologically active secondary metabolites isolated from plants, the flavonoids are the most frequently cited. The coumestan wedelolactone from Eclipta prostata and some of its synthetic derivatives are the most active PLA2 inhibitors. ${ }^{8}$ The prenylated pterocarpan edunol and its synthetic derivatives showed antimyotoxic, antiproteolytic and PLA2 inhibitor properties. ${ }^{9}$ In addition, Nakagawa et $a l .{ }^{10}$ indicated the cabenegrines A-I and A-II as the responsible for anti-ophidian activity of the "Específico Pessoa", a phytotherapic tincture of the Brazilian folk medicine used against snakebites.

Harpalyce brasiliana Benth (LeguminoseaePapilionoideae), popularly known in Northeast of Brazil as "raiz-de-cobra" (Port. Lit.: snake's root), is reported as a medicinal antidote to snake bites through the use of a hydroalcohol solution from its roots. We have previously

*e-mail: edil@ufc.br reported the structure of several prenylated pterocarpans, ${ }^{11-13}$ reputed as possessing venoms antidote properties. ${ }^{9,10}$ In continuation to the search for bioactive flavonoids from the roots of $H$. brasiliana, we are reporting now the structure elucidation of the novel geranyl-flavanone (-)-7,8,3',4'-trihydroxy-8-(3", 7"'-dimethyl-octa-2",6"dienoyl)-flavanone (1), along with the known pterocarpans (-)-2-geranyl- 3-hydroxy-8,9-methylenedioxypterocarpan (2), ${ }^{14}$ harpalicin (3), ${ }^{12}$ medicarpin (4), ${ }^{15}$ maackiain $(5)^{16}$ and cabenegrins A-I (6) and A-II (7). ${ }^{10}$<smiles>CC(C)=CCCC1=C[CH]C2=C(O1)C(=O)CC(c1ccc(O)c(O)c1)O2</smiles>

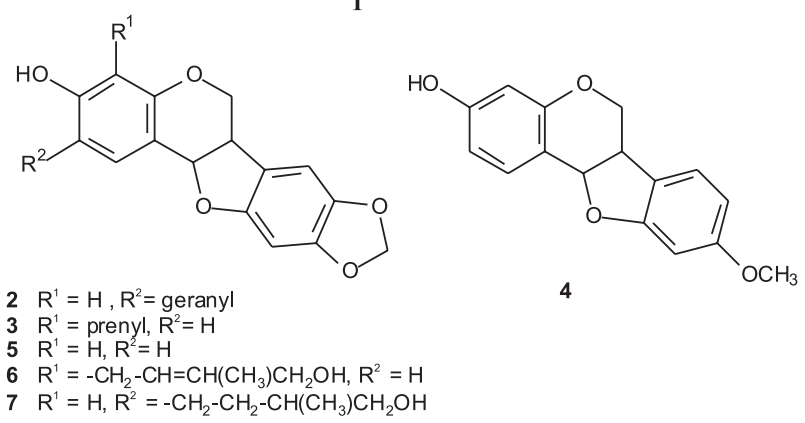




\section{Results and Discussion}

Compound $\mathbf{1}$ was isolated as a yellow solid with $\mathrm{mp}$ 96.3-97.1 ${ }^{\circ} \mathrm{C}$ and optical rotation $-108^{\circ}\left(\mathrm{CHCl}_{3} ; c 0.1\right)$. Its molecular formula of $\mathrm{C}_{22} \mathrm{H}_{24} \mathrm{O}_{11}$ was established by the quasi-molecular ion at $m / z 409.20157[\mathrm{M}+\mathrm{H}]^{+}$ in the HRESIMS spectrum. The absorption bands at $3366 \mathrm{~cm}^{-1}$ and 1748 in the IR spectrum, were consistent with hydroxyl and carbonyl groups, respectively. The analysis of ${ }^{1} \mathrm{H}$ NMR spectrum in addition to the COSY experiment data revealed the presence of two sets of $\mathrm{ABX}$ coupling system protons, through the correlations of the aromatic hydrogens at $\delta 6.93(\mathrm{dd}, J 1.6,8.2 \mathrm{~Hz}$, H-2'), 6.81 (dd, $\left.J 1.6,8.2 \mathrm{~Hz}, \mathrm{H}-6^{\prime}\right)$ and 6.78 (d, $J 8.2$ $\left.\mathrm{Hz}, \mathrm{H}-5^{\prime}\right)$, and of the hydrogens of a typical flavanone skeleton at $\delta 5.26(\mathrm{dd}, J 2.8,12.9 \mathrm{~Hz}, \mathrm{H}-2), 2.96(\mathrm{dd}, J$ $12.9,16.9 \mathrm{~Hz}, \mathrm{H}-3)$ and $2.68\left(\mathrm{dd}, J 2.8,16.9, \mathrm{H}-3^{\prime}\right) .{ }^{17}$ The presence of a geranyl group was suggested from the characteristic signals of the three methyl groups at $\delta 1.59$ (s, H-10'), 1.57 (s, H-8' ${ }^{\prime \prime}$ ) and 1.52 (s, H-9'), two olefinic hydrogens at $\delta 5.02\left(\mathrm{t}, J 6.0 \mathrm{~Hz}, \mathrm{H}-6^{\prime \prime}\right)$ and 5.17 (t, $\left.J 7.8 \mathrm{~Hz}, \mathrm{H}-2^{\prime \prime}\right)$, and three methylenes at $\delta 2.01$ (d, $\left.J 7.8 \mathrm{~Hz}, \mathrm{H}-4^{\prime \prime}\right), 2.09$ (m, H-5") and 3.44 (d, J 7.0 $\left.\mathrm{Hz}, \mathrm{H}-1^{\prime \prime}\right)$. In the aromatic region of the spectrum, the two remaining aromatic protons occurred as a set of orto coupled doublets at $\delta 6.50(\mathrm{~d}, J 8.7 \mathrm{~Hz}, \mathrm{H}-6)$ and 7.57 (d, J $8.7 \mathrm{~Hz}, \mathrm{H}-5$ ).

The support for a geranyl-flavanone structure came from the comparative analysis of the ${ }^{13} \mathrm{C}$ NMR and DEPT spectra that indicated the presence of signals for 25 carbon atoms, revealing $16 \mathrm{sp}^{2}$ carbons, from which 10 non-hydrogenated and 8 methines. The remaining signals comprised one carbonyl ( $\delta$ 194.3), four methylenes, one oxygenated methine and three methyl groups (Table 1).

The assignment of the relative position of the geranyl moiety was defined in the HMBC spectrum by the cross-peaks of the allylic methylene protons at $\delta 3.44$ (H-1") with the carbons at $\delta 163.2$ (C-7) and 164.1 (C-9), in addition to the correlation of the signal at $\delta 7.57$ (H-5) with the carbonyl at $\delta 194.3(\mathrm{C}-4)$ and the carbon at $\delta 163.2(\mathrm{C}-7)$, and of the hydrogen at $\delta 7.57$ $(\mathrm{H}-5)$ with the carbons at $\delta 115.2(\mathrm{C}-8)$ and $163.2(\mathrm{C}-7)$. These correlation data of the A-ring protons definitively established that the $\mathrm{OH}$ and geranyl groups were located at the $\mathrm{C}-7$ and $\mathrm{C}-8$, respectively. Moreover, the concomitant correlations of the hydrogens of the B-ring at $\delta 6.81$ (H-6') and $6.93\left(\mathrm{H}-2^{\prime}\right)$ with the carbons at $\delta 81.0(\mathrm{C}-2)$ and $81.0\left(\mathrm{C}-4^{\prime}\right)$ confirmed the respective relative locations at $\mathrm{C}^{-3} \mathbf{3}^{\prime}$ and $\mathrm{C}-4^{\prime}$ of the two hydroxyl groups in the trisubstituted aromatic, and gave the clear evidence of a $7,8,3^{\prime}, 4^{\prime}$-substitution pattern for the flavanone moiety.
Table 1. ${ }^{1} \mathrm{H}$ and ${ }^{13} \mathrm{C}$ NMR data for compound $\mathbf{1}^{\mathrm{a}}$

\begin{tabular}{|c|c|c|}
\hline Carbon & ${ }^{1} \mathrm{H} \operatorname{NMR}\left(\delta_{\mathrm{H}}\right)$ & ${ }^{13} \mathrm{C}$ NMR $\left(\delta_{\mathrm{C}}\right)$ \\
\hline 2 & $5.26 \mathrm{dd}(2.8 ; 12.9)$ & 81.0 \\
\hline 3 & $\begin{array}{c}2.68 \mathrm{dd}(2.8 ; 16.9) \\
2.96 \mathrm{dd}(12.9 ; 16.9)\end{array}$ & 45.1 \\
\hline 4 & & 194.3 \\
\hline 5 & $7.57 \mathrm{~d}(8.7)$ & 126.8 \\
\hline 6 & $6.50 \mathrm{~d}(8.7)$ & 111.0 \\
\hline 7 & & 163.2 \\
\hline 8 & & 115.2 \\
\hline 9 & & 164.1 \\
\hline 10 & & 114.9 \\
\hline $1^{\prime}$ & & 132.1 \\
\hline $2^{\prime}$ & $6.93 \mathrm{dd}(1.6 ; 8.2)$ & 114.9 \\
\hline $3^{\prime}$ & & 146.8 \\
\hline $4^{\prime}$ & & 146.6 \\
\hline $5^{\prime}$ & $6.78 \mathrm{~d}(8.2)$ & 115.2 \\
\hline $6^{\prime}$ & $6.81 \mathrm{dd}(1.6 ; 8.2)$ & 119.3 \\
\hline $1^{\prime \prime}$ & $3.44 \mathrm{~d}(7.8)$ & 23.0 \\
\hline $2^{\prime \prime}$ & $5.17 \mathrm{t}(7.8)$ & 123.5 \\
\hline $3^{\prime \prime}$ & & 136.0 \\
\hline $4^{\prime \prime}$ & $2.01 \mathrm{~d}(7.8)$ & 41.0 \\
\hline $5^{\prime \prime}$ & $2.09 \mathrm{~m}$ & 26.6 \\
\hline $6^{\prime \prime}$ & $5.02 \mathrm{t}(6.0)$ & 125.6 \\
\hline $7^{\prime \prime}$ & & 132.5 \\
\hline $8^{\prime \prime}$ & $1.57 \mathrm{~s}$ & 26.0 \\
\hline $9^{\prime \prime}$ & $1.52 \mathrm{~s}$ & 17.9 \\
\hline $10^{\prime \prime}$ & $1.59 \mathrm{~s}$ & 16.5 \\
\hline
\end{tabular}

${ }^{a}{ }^{1} \mathrm{H}$ and ${ }^{13} \mathrm{C}$ NMR spectra were acquired in $\mathrm{CD}_{3} \mathrm{OD}$ at 300 and $75 \mathrm{MHz}$, respectively. Chemical shifts are shown in the $\delta$ scale and the coupling constants $(J$ values in $\mathrm{Hz})$ are given in parentheses.

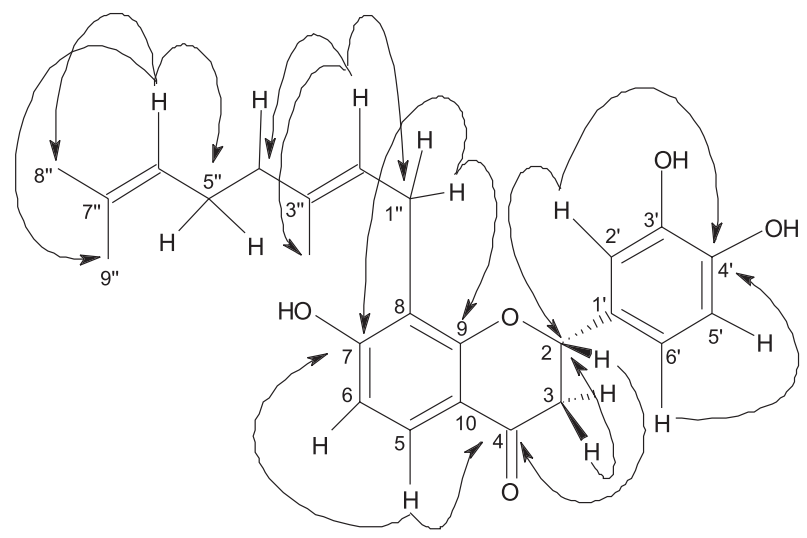

Figure 1. Key HMBC correlations observed for compound 1.

Based on these findings, the structure of $\mathbf{1}$ was proposed to be the new (-)-7, 8, 3', 4'-trihydroxy-8-(3",7"-dimethylocta-2",6"-dienoyl)-flavanone.

The isolated compounds were tested for their cytotoxicity using five tumor cell lines: two human leukemias (HL-60 
and CEM), human breast adenocarcinoma (MCF-7), human colon adenocarcinoma (HCT-8) and murine melanoma (B16), but none showed any cytotoxic activity.

\section{Experimental}

\section{General procedures}

IR spectra were recorded using a Perkin Elmer 1000 FT-IR spectrophotometer. Optical rotations were measured on a Perkin Elmer 341 polarimeter. The mass spectra were obtained on a Hewlett-Packard 5971 mass spectrometer by electron impact ionization $(70 \mathrm{eV}) .{ }^{1} \mathrm{H}$ and ${ }^{13} \mathrm{C}$ NMR spectra were recorded on a Bruker Avance DRX-500 (500 MHz for ${ }^{1} \mathrm{H}$ and $125 \mathrm{MHz}$ for ${ }^{13} \mathrm{C}$ ); chemical shifts were expressed in $\delta$ scale and were referenced to residual $\mathrm{CD}_{3} \mathrm{OD}(3.31$ and 49.15 ppm). Silica Gel 60 (Merck, 230-400 mesh) was used for analytical TLC. Column chromatographies were performed over Sephadex LH-20 (Amersham Pharmacia Biotech AB, Sweden) and silica gel (Merck, $60 \mathrm{~F}_{254}$ 230-240 mesh). HPLC separations were conducted on a Waters-1525 pumping system equipped with a PDA detector Waters-2996 (265 nm) and a XTerra RP-18 column $\left(4.6 \times 250 \mathrm{~mm}, 5 \mu \mathrm{mol} \mathrm{L}{ }^{-1}\right)$. All compounds were visualized on TLC by spraying with vanillin/perchloric acid/EtOH followed by heating.

\section{Plant material}

Roots of Harpalyce brasiliana Benth were collected at Chapada do Araripe, Crato, Ceará State, and authenticated by Prof. Edson P. Nunes of the Departamento de Biologia, Universidade Federal do Ceará, CE, Brasil. Voucher specimen (32525) has been deposited at the Herbário Prisco Bezerra (EAC), Departamento de Biologia, Universidade Federal do Ceará, Fortaleza, Ceará, Brazil.

\section{Extraction and isolation}

Roots of Harpalyce brasiliana $(3.5 \mathrm{~kg})$ were pulverized and extracted with $\mathrm{EtOH}$ at room temperature. The solvent was removed under reduced pressure to give a dark viscous extract (260.0 g). Liquid-liquid partition of an aliquot of the EtOH extract (100.0 g) using petrol ether, $\mathrm{CHCl}_{3}$, EtOAc and $\mathrm{n}-\mathrm{BuOH}$ as solvents yielded four fractions. The $\mathrm{CHCl}_{3}$ fraction $(30.0 \mathrm{~g})$ was further purified over Sephadex LH-20 by elution with $\mathrm{MeOH}$ to give five fractions (F1-to F-5). Flash chromatography of F-3 (8.9 g) using $\mathrm{CHCl}_{3}$, EtOAc and $\mathrm{MeOH}$ as binary mixtures of increasing polarity afforded 73 fractions, which were pooled to 17 fractions after TLC analysis.
The sub-fraction F-3 (1-3) was further purified by HPLC using a mixture of $\mathrm{CH}_{3} \mathrm{CN} / \mathrm{H}_{2} \mathrm{O}(80 / 20$, v/v) (flow rate $\left.4.72 \mathrm{~mL} \mathrm{~min}^{-1}\right)$, to yield the (-)-2-geranyl- 3-hydroxy-8,9methylenedioxypterocarpan (2) (10.0 mg) and harpalicin (3) $(3.0 \mathrm{mg})$. Using the same method, sub-fraction F-3 (911) $(50.0 \mathrm{mg})$ was purified, using a mixture of acetonitrile/ $\mathrm{H}_{2} \mathrm{O}\left(60 / 40, \mathrm{v} / \mathrm{v}\right.$ ) (flow rate $4.7 \mathrm{~mL} \mathrm{~min}^{-1}$ ) as eluent, to yield medicarpin (4) $(4.0 \mathrm{mg})$ and maackiain $(\mathbf{5})(12.0 \mathrm{mg})$. Purification of sub-fraction F-3 (23-29) (100.0 mg) using a mixture of acetonitrile/ $\mathrm{H}_{2} \mathrm{O}(50 / 50, \mathrm{v} / \mathrm{v}$ ) (flow rate $\left.4.72 \mathrm{~mL} \mathrm{~min}^{-1}\right)$ afforded cabenegrins A-I (6) (29.0 mg) and A-II (7) (35.0 mg). The compound (-)-7,8,3',4'-Trihydroxy8-(octa-2", 6"'-dienoyl-3", 7"'-dimethyl)-flavanone $\mathbf{1}$ $(28.0 \mathrm{mg})$ was obtained from sub-fraction F-3 (37-44) $\left(40.0 \mathrm{mg}\right.$ ) by elution with a mixture of acetonitrile/ $\mathrm{H}_{2} \mathrm{O}$

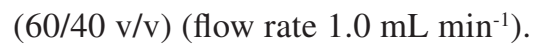

\section{Cytotoxic assay}

All compounds were tested for cytotoxic activity against five tumor cells lines (National Cancer Institute, Bethesda, MD); B16 (murine melanoma), HCT-8 (human colon), MCF-7 (human breast), CEM and HL-60 (leukemia) after $72 \mathrm{~h}$ of incubation. Doxorubicin (0.01 to $\left.0.58 \mu \mathrm{g} \mathrm{mL}^{-1}\right)$ was used as positive control. The general viability of culture cells was determined by reduction of yellow dye 3-(4,5-dimethyl-2-thiazolyl)-2,5-diphenyl-2 $\mathrm{H}$-tetrazolium bromide (MTT) to a blue formazan product as described by Mosmann. ${ }^{18}$

(-)-7,8,3',4'-Trihydroxy-8-(3", 7'”-dimethyl-octa-2",6"'dienoyl)-flavanone (1)

Yellow solid. mp 96.3-97.1 ${ }^{\circ} \mathrm{C}$. $[\alpha]_{\mathrm{D}}^{20}-108^{\circ}\left(\mathrm{CHCl}_{3}\right.$; $c$ 0.1). IR (film) $v_{\max } / \mathrm{cm}^{-1}: 3366,2925,2852,1748,1493$, 1380, 1347, 1131, 1092, 1073, 1002, 944, 823, 702. HRESIMS $[\mathrm{M}+\mathrm{H}] 409.20157$ (calculated for $\mathrm{C}_{25} \mathrm{H}_{29} \mathrm{O}_{5}$ 409.2016). EIMS $m / z 408$ ([M] 10\%), 393, 365, 339, 285, 272, 229, 203, 161, 149, 136, 123, 69, 41. ${ }^{1} \mathrm{H}$ and ${ }^{13} \mathrm{C}$ NMR data are given in Table 1.

\section{Cabenegrin A-II (7)}

White solid. mp $162.8-169.6{ }^{\circ} \mathrm{C} .[\alpha]_{\mathrm{D}}^{20}-190^{\circ}(\mathrm{MeOH}$; $c 0.02$ ). IR (film) $\mathrm{v}_{\max } / \mathrm{cm}^{-1}: 3399,2915,1622,1509,1472$, 1376, 1326, 1252, 1139, 1120, 1034, 933, 847, 766. EIMS m/z. 370 ([M] 10\%), 297, 267, 175, 162, 148, 115, 91, 77, 69, 53. ${ }^{1} \mathrm{H}$ NMR (identical to literature) ${ }^{10} \cdot{ }^{13} \mathrm{C}$ NMR: 17.3 (C-5'), 28.2 (C-1'), 35.0 (C-2'), 36.8 (C-3'), 41.8 (C-6a), 67.6 (C-6), 68.7 (C-4'), 80.4 (C-11a), 94.4 (C-10), 102.6 (C-6'), 103.8 (C-4), 106.1 (C-7), 112.6 (C-1a), 120.1 (C7a), 124.8 (C-2), 133.1(C-1), 143.2 (C-8), 149.5 (C-9), 156.0 (C-4a), 155.7 (C-10a), 157.8 (C-3). 


\section{Acknowledgments}

The authors are grateful to CNPQ, CAPES, PRONEX, FINEP and FUNCAP for the fellowships and financial support.

\section{Supplementary Information}

${ }^{1} \mathrm{H}$ NMR, ${ }^{13} \mathrm{C}$ NMR, COSY, HMQC, HMBC, IR and EIMS spectra of compound $\mathbf{1}$ are available free of charge at http:jbcs.sbq.org.br, as PDF file.

\section{References}

1. Borges, M. H.; Soares, A. M.; Rodrigues, V. M.; AndriãoEscarso, S. H.; Diniz, H.; Hamaguchi, A., Quintero, A.; Lizano, S.; Gutiérrez, J. M.; Giglio, J. R.; Homsi-Brandeburgo, M. I.; Comp. Biochem. Physiol. 2000, 127, 21.

2. Borges, M. H.; Soares, A. M.; Rodrigues, V. M.; Oliveira, F.; Franceschi, A. M.; Rucavado, A.; Giglio, J. R.; HomsiBrandeburgo M. I.; Toxicon 2001, 39, 1863.

3. Rodrigues, V. M.; Marcussi, S.; Cambraia, R. S.; Araújo A. L.; Malta-Neto, N. R.; Hamaguchi, A.; Ferro, E. V.; Giglio, J. R.; Homsi-Brandeburgo, M. I.; Soares, A. M.; Toxicon 2004, 44, 305.

4. Biondo, R.; Pereira, A. M.; Marcussi, S.; Pereira, P. S.; França, S. C.; Soares, A. M.; Biochimie 2003, 85, 1017.

5. Biondo, R.; Soares, A. M.; Bertoni, B. W.; França, S. C.; Pereira, A. M.; Plant Cell. Rep. 2004, 22, 549.
6. Januario, A. H.; Santos, S. L.; Marcussi, S.; Mazzi, M. V.; Pietro, R. C. L. R.; Sato, D. N.; Ellena, J.; Sampaio, S. V.; Franca, S. C.; Soares, A. M.; Chem.-Biol. Interact. 2004, 150, 243.

7. Pereira, B. M. R.; Daros, M. P.; Parente, J. P.; Matos, F. J. A.; Phytother. Res. 1996, 10, 666.

8. Silva, A. J. M.; Melo, P. A.; Silva, N. M.; Brito, F. V.; Buarque, C. D.; Souza, D.V.; Rodrigues, V. P.; Poças, E. S.; Noel, F.; Albuquerque, E.X.; Costa, P. R. R.; Bioorg. Med. Chem. Lett. 2001, 11, 283.

9. Silva, A. J. M.; Coelho, A. L.; Simas, A. B. C.; Moraes, R. A. M.; Pinheiro, D. A.; Fernandes, F. A. F.; Arruda, E. Z.; Costa, P. R. R.; Melo, P. A.; Bioorg. Med. Chem. Lett. 2004, 14, 431.

10. Nakagawa, M.; Nakanishi, K.; Darko, L. L.; Vick, J. A.; Tetrahedron Lett. 1982, 23, 3855.

11. Silva, G. L.; Machado, M. I. L.; Matos, F. J. A.; Braz-Filho, R.; J. Braz. Chem. Soc. 1999, 10, 438.

12. Silva, G. L.; Matos, F. J. A.; Silveira, E. R.; Phytochemistry 1997, 46, 1059.

13. Militão, G. C. G.; Pinheiro, S. M.; Dantas, I. N. F.; Pessoa, C.; Moraes, M. O.; Costa-Lotufo, L. V.; Lima, M. A. S.; Silveira, E. R.; Bioorg. Med. Chem. 2007, 15, 6687.

14. Vieira, N. C.; Espíndola, L. S.; Santana, J. M.; Veras, M.. L.; Pessoa, O. D. L.; Pinheiro, S. M.; Araújo, R. M.; Lima, M. A. S.; Silveira, E. R.; Bioorg. Med.Chem. 2008, 16, 1676.

15. Dannhardt, G.; Schneider, G.; Schwell, B.; Pharm. Pharmacol. Lett. 1992, 2, 161.

16. Bedir, E.; Çalis, I.; Aquino, R.; Piacente, S.; Pizza, C.; Phytochemistry 1999, 51, 1017.

17. Freitas, M. O.; Lima, M. A. S.; Silveira, E. R.; Quim. Nova 2007, 30, 1926.

18. Mosmann, T.; J. Immunol. Methods 1983, 16, 55.

Received: August 20, 2008

Web Release Date: April 17, 2009 


\section{Pterocarpans and a Novel Flavanone from Harpalyce brasiliana Roots}

\section{Renata M. de Araújo, Mary Anne S. Lima and Edilberto R. Silveira* \\ Departamento de Química Orgânica e Inorgânica, Centro de Ciências, Universidade Federal do Ceará, CP 12200, 60451-970 Fortaleza-CE, Brazil}

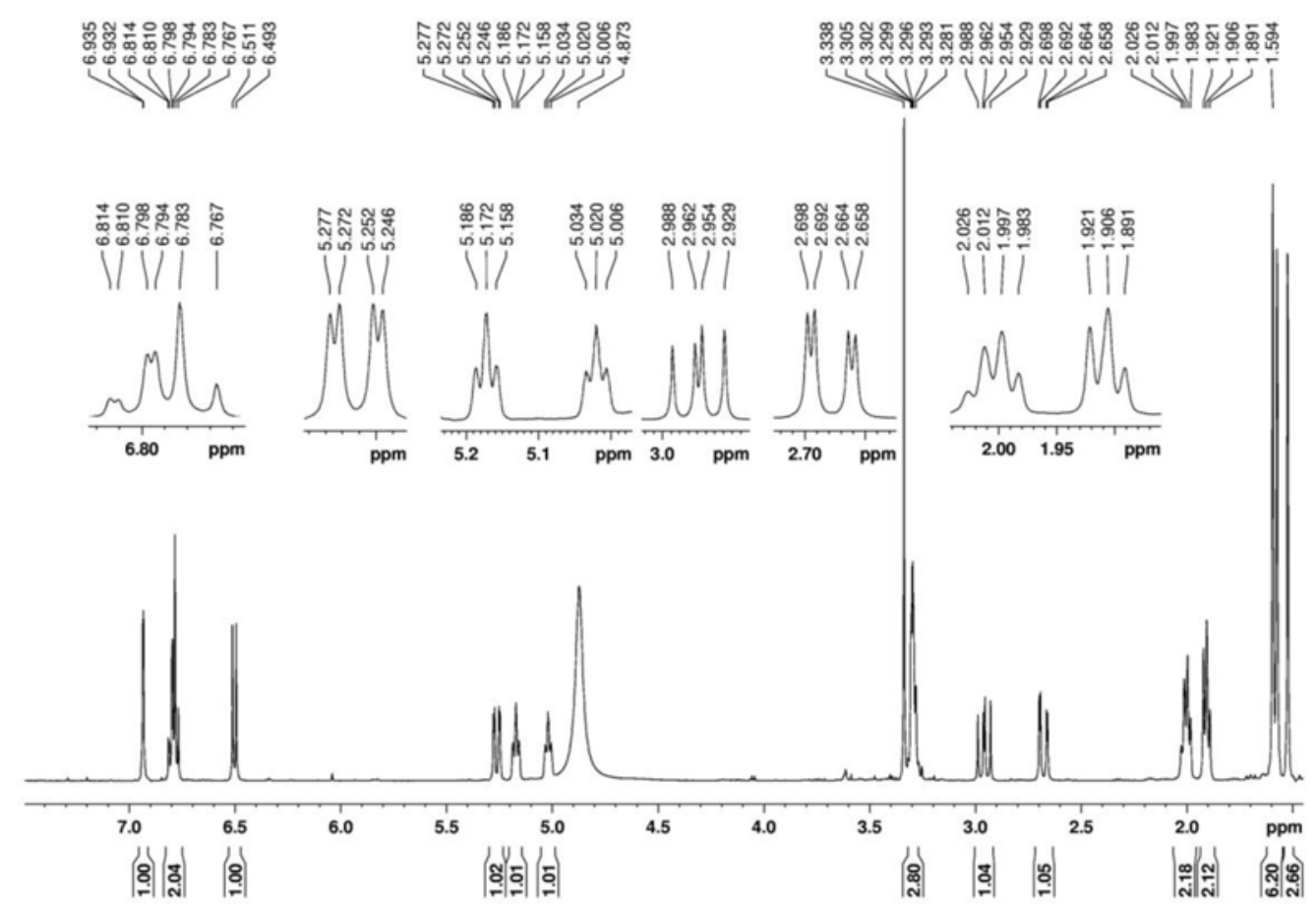

Figure S1. ${ }^{1} \mathrm{H}$ NMR spectrum $\left(500 \mathrm{MHz}, \mathrm{CD}_{3} \mathrm{OD}\right)$ of compound $\mathbf{1}$. 

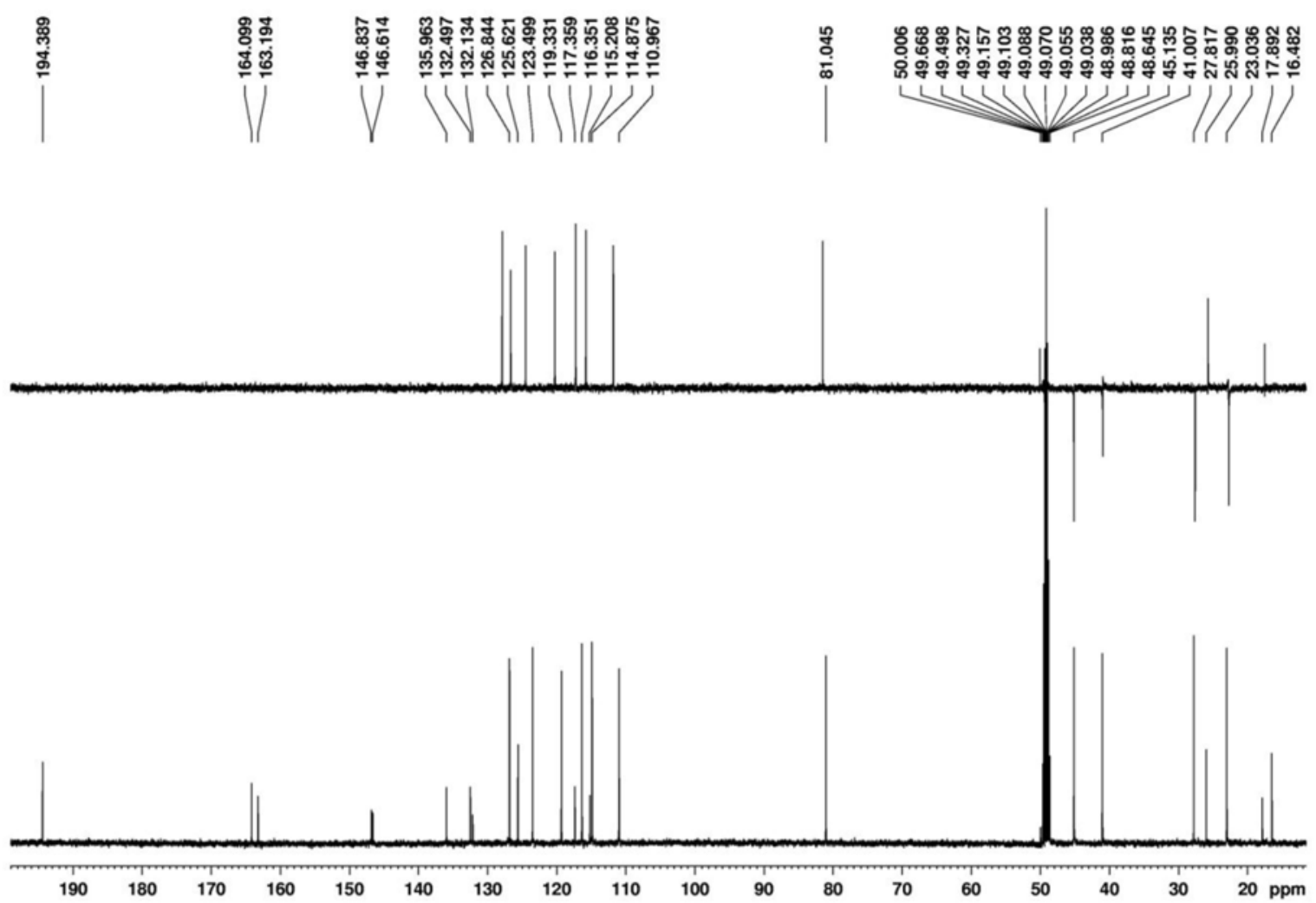

Figure S2. ${ }^{13} \mathrm{C}$-BB and DEPT $135 \mathrm{NMR}$ spectrum (125 MHz, CD $\mathrm{OD}$ ) of compound $\mathbf{1}$.

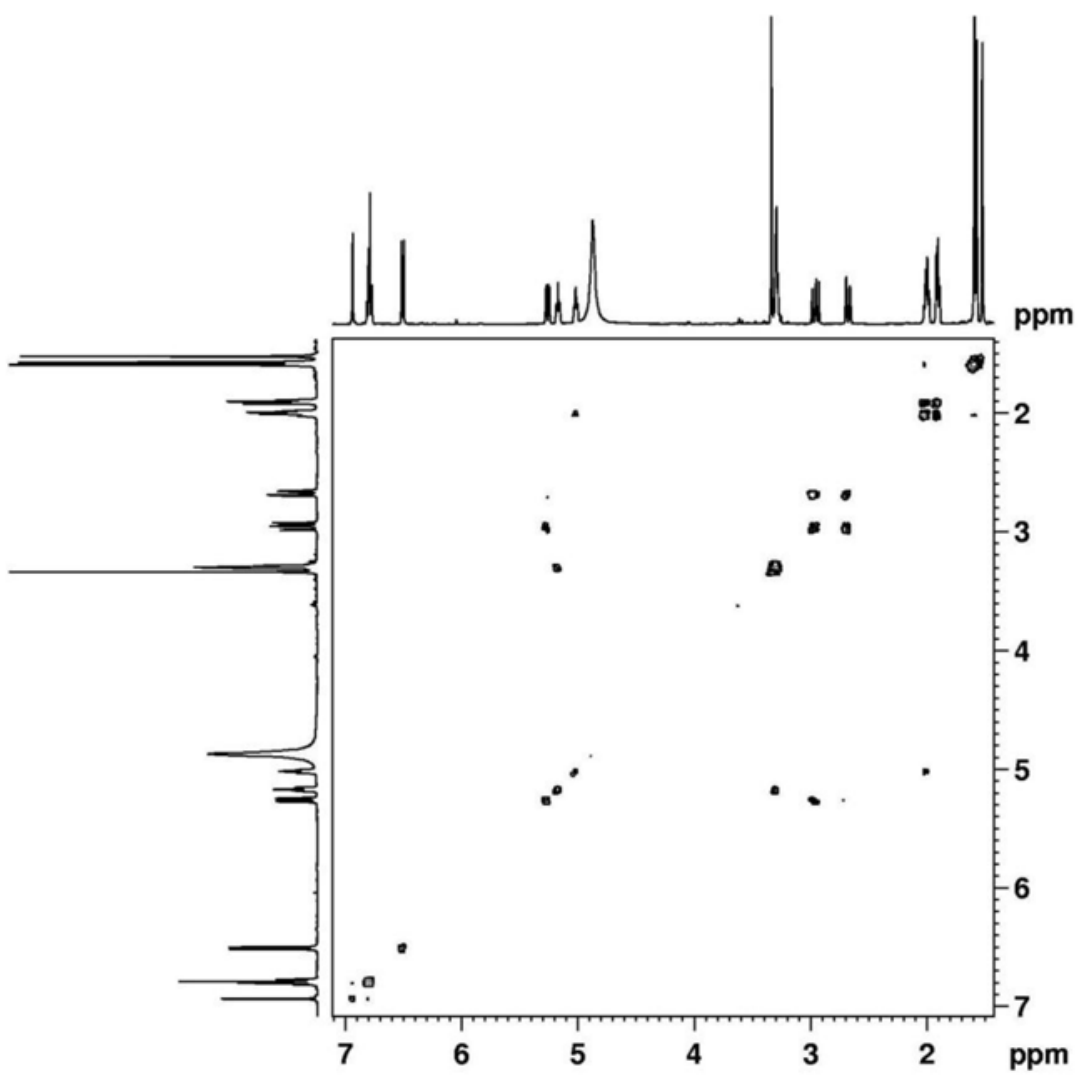

Figure S3. COSY spectrum $\left(\mathrm{CD}_{3} \mathrm{OD}\right)$ of compound 1. 


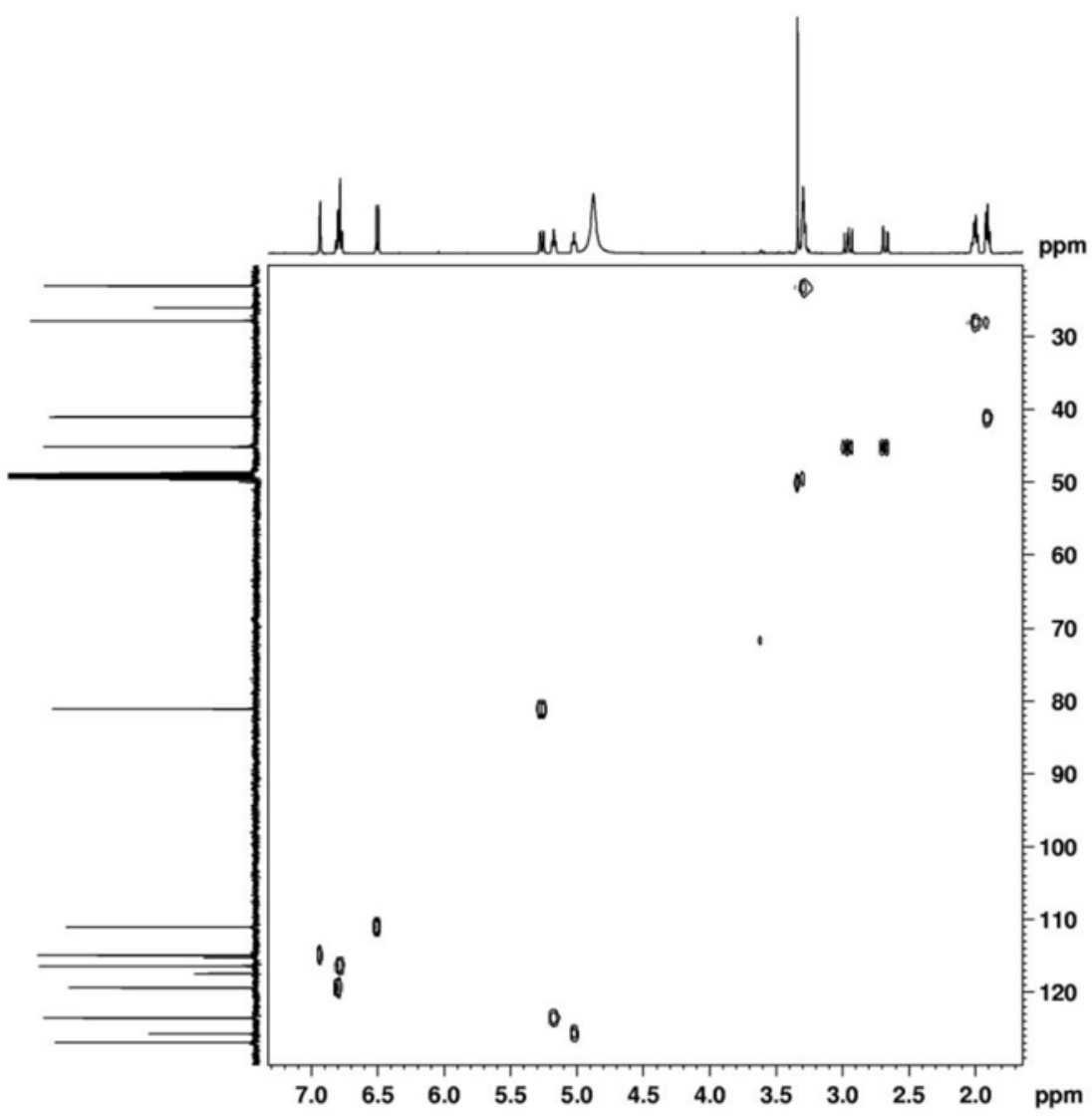

Figure S4. няес spectrum $\left(\mathrm{CD}_{3} \mathrm{OD}\right)$ of compound 1.

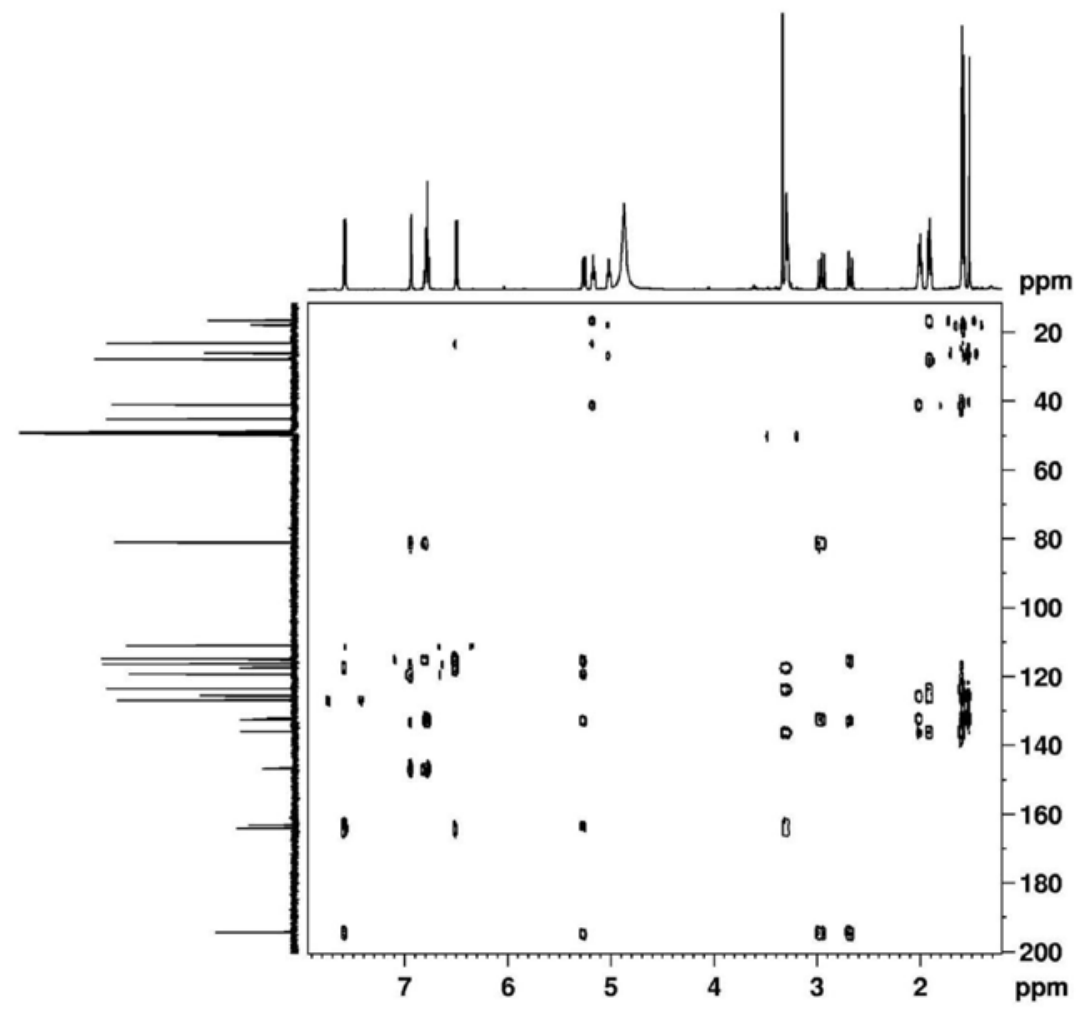

Figure S5. $\mathrm{HMBC}$ spectrum $\left(\mathrm{CD}_{3} \mathrm{OD}\right)$ of compound $\mathbf{1}$. 


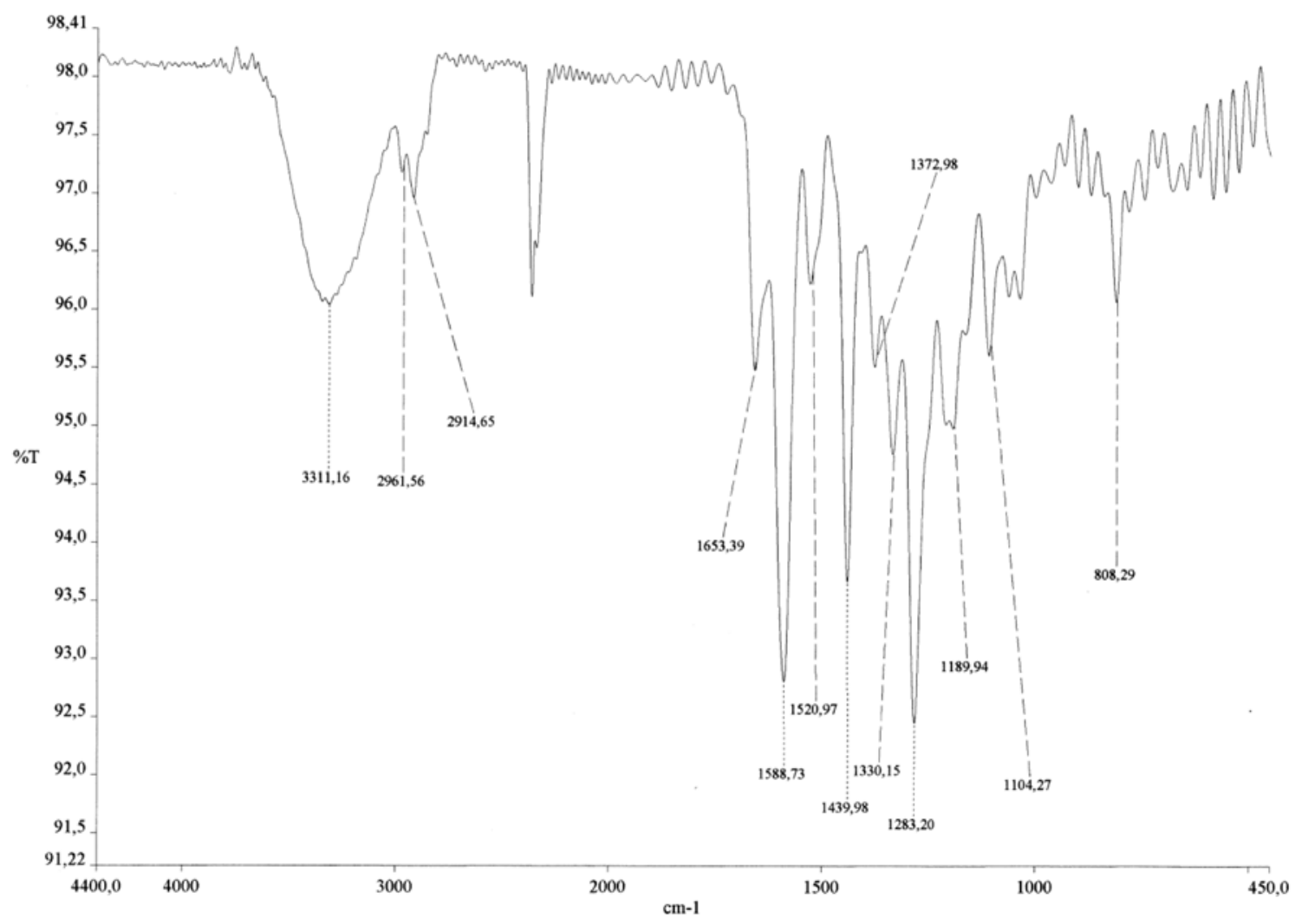

Figure S6. IR spectrum of compound $\mathbf{1}$.

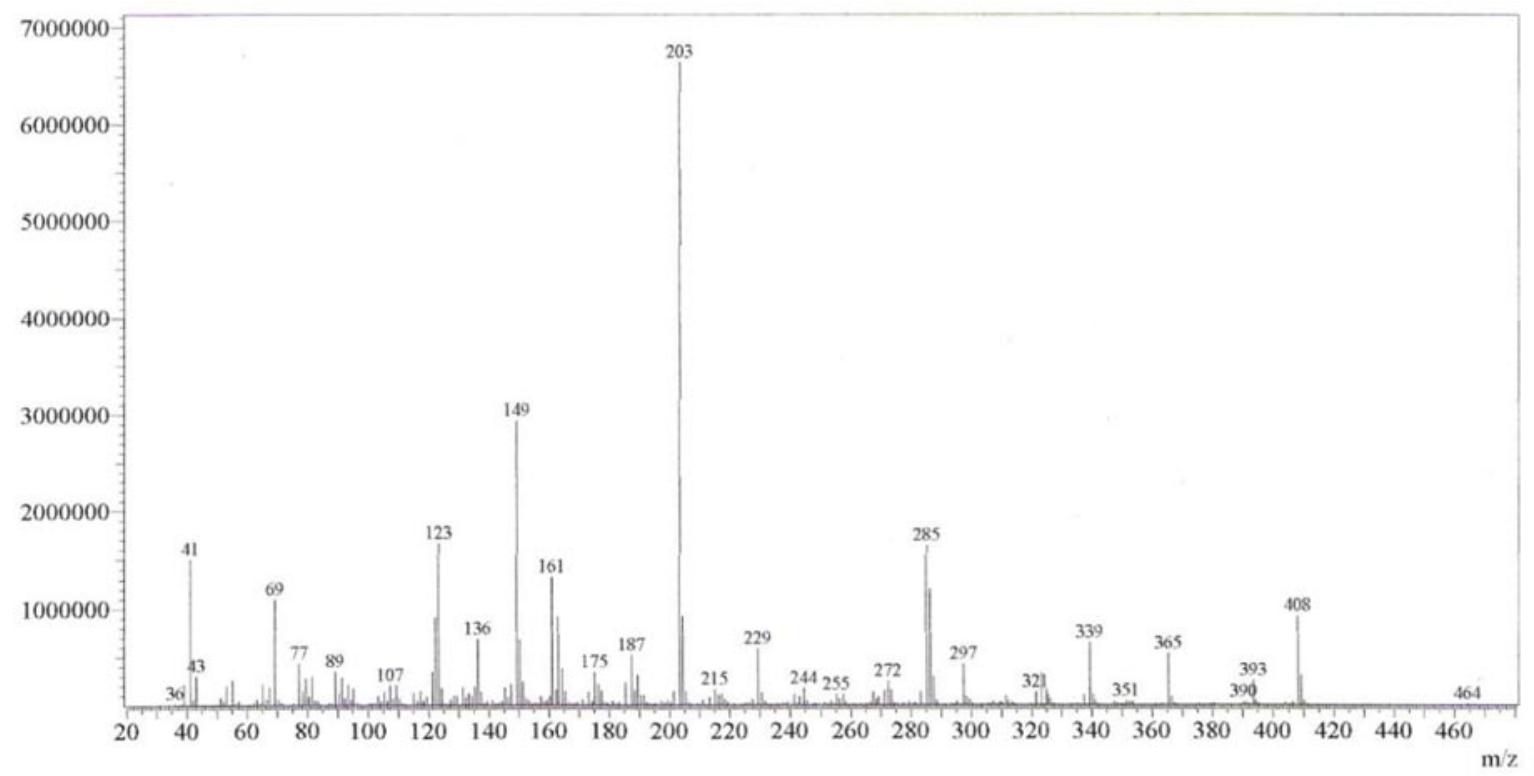

Figure S7. EIMS spectrum of compound $\mathbf{1}$. 